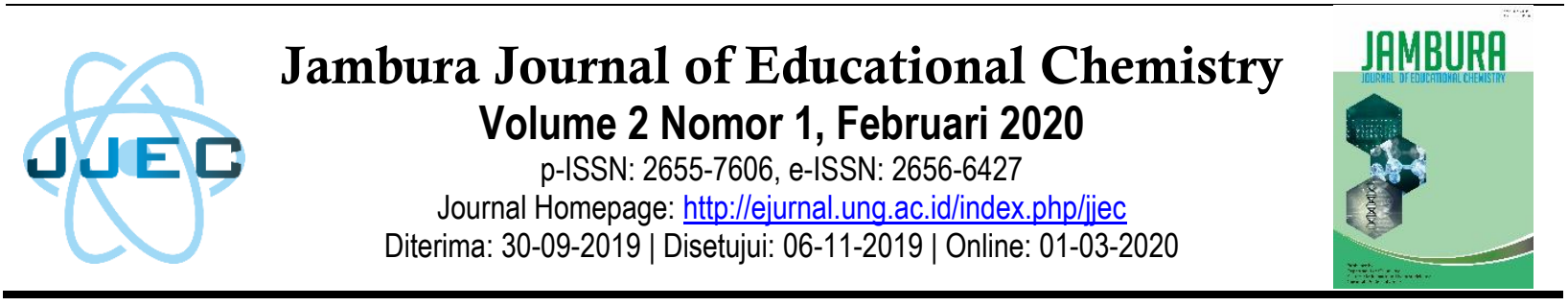

\title{
Kegiatan Laboratorium Kimia Berbasis Mini-Project Terhadap Hasil Belajar dan Aktivitas Siswa pada Praktikum Uji Aldehid
}

\author{
Anis Trisusilosakti1 ${ }^{*}$, Ratna Sari Siti Aisyah ${ }^{2}$ \\ 1,2Jurusan Pendidikan Kimia FKIP Universitas Sultan Ageng Tirtayasa, Jalan Raya Ciwaru No.25 \\ Serang \\ e-mail: anistrisusilosakti@gmail.com
}

\begin{abstract}
Abstrak: Kegiatan praktikum kimia di sekolah cenderung hanya membuat siswa melaksanakan panduan yang sudah ditentukan. Maka diperlukan suatu pembelajaran yang dapat mengajak siswa terlibat lebih aktif yaitu pembelajaran berbasis Mini-Project. Penelitian ini bertujuan untuk mengetahui penerapan kegiatan laboratorium kimia berbasis Mini-Project terhadap hasil belajar dan aktivitas siswa. Peningkatan hasil belajar ditunjukkan oleh hasil pre-test dan post-test, sedangkan peningkatan aktivitas siswa ditunjukkan oleh hasil observasi. Penelitian ini menggunakan metode quasy-experimental dengan control group pre-test post-test design. Sampel dalam penelitian ini berjumlah 64 siswa. Instrumen penelitian menggunakan tes tertulis (pre-test dan post-test), dan lembar observasi yang sudah divalidasi. Data penelitian dianalisis secara deskriptif dan statistik. Hasil penelitian menunjukkan bahwa penerapan pembelajaran berbasis Mini-Project dapat meningkatkan hasil belajar dan aktivitas siswa dengan ukuran pengaruh dalam kategori "besar".
\end{abstract}

Kata kunci: Mini-Project, uji aldehid, hasil belajar, aktivitas siswa

\section{PENDAHULUAN}

Kimia merupakan salah satu pelajaran yang membutuhkan penguasaan konsep yang baik. Banyak siswa yang menganggap kimia itu sulit, karena materi yang dipelajari bersifat abstrak. Sehingga dalam pembelajaran kimia perlu dilakukan suatu praktikum atau eksperimen, agar mempermudah siswa dalam memahami materi yang mereka pelajari (Pamungkas et al., 2017). Praktikum erat kaitannya dengan pembelajaran kimia untuk memperoleh pengalaman, keterampilan, dan bukti nyata dari prinsip, konsep, hukum dasar, juga teori kimia yang bersifat abstrak (Aeni et al., 2017).

Kegiatan belajar dikenal dalam dua jenis yaitu belajar produk dan belajar proses. Kegiatan praktikum memungkinkan siswa belajar proses. Pengalaman yang diperoleh siswa ketika praktikum, akan mendorong siswa untuk lebih memahami materi yang mereka pelajari. Belajar produk hanya menekankan segi kognitif saja. Hal ini mengakibatkan kemampuan siswa hanya sekedar kemampuan menghafal. Siswa kurang diberikan kesempatan untuk mengembangkan rasa tanggung jawab, kejujuran, kreativitas, dan rasa percaya diri (Permatasari \& Marwoto, 2017). Sedangkan belajar proses memungkinkan tercapainya tujuan belajar dari segi kognitif, afektif, dan psikomotor (Kurniawati et al., 2015).

Pembelajaran yang diterapkan di sekolah seharusnya mampu meningkatkan aktivitas siswa serta memberikan kontribusi yang berarti terhadap hasil belajar (Erlinda, 2017). Menurut Sudjana hasil belajar adalah kecakapan siswa setelah mendapatkan pengalaman belajar, dan ditentukan oleh siswa itu sendiri yang ingin membangun 
pengetahuannya (Barus \& Sani, 2017). Berkaitan dengan upaya mencapai hasil belajar yang baik, seorang guru perlu meningkatkan kualitas pembelajaran. Hal tersebut dapat dilakukan melalui pembelajaran yang lebih banyak melibatkan peran siswa sehingga meningkatkan keaktifan siswa. Ada banyak pilihan terkait metode, model, media pembelajaran aktif dan interaktif, namun metode konvensional masih menjadi andalan para guru dalam mengajarkan kimia. Metode konvensional yang terlihat lebih efektif dari segi waktu, pada kenyataannya kurang memberikan dampak terhadap aktivitas belajar siswa (Taher, 2019).

Aktivitas siswa dalam suatu pembelajaran sangat menentukan hasil belajar. Ketika siswa aktif, maka hasil belajar siswa juga akan meningkat (Suarta et al., 2017). Menurut Sardiman aktivitas siswa adalah sebuah aktivitas berupa aktivitas fisik maupun mental. Pada proses pembelajaran kedua aktivitas tersebut saling berkaitan, sehingga menghasilkan aktivitas belajar yang optimal (Agustin et al., 2017). Aktivitas yang diamati dalam penelitian ini yaitu Visual activities, Oral activities, Listening activities, Writing activities, Motor activities, dan Mental activities.

Pembelajaran berbasis proyek merupakan suatu pembelajaran yang memungkinkan pendidik untuk mengelola pembelajaran melalui kerja proyek (Yunita et al., 2016). Pembelajaran berbasis proyek yang dapat diaplikasikan dalam pembelajaran kimia salah satunya yaitu pembelajaran berbasis Mini-Project. Pembelajaran berbasis Mini-Project merupakan suatu pembelajaran menggunakan metode proyek yang terdiri dari delapan tahapan (Hakim et al., 2015).

Berdasarkan uraian di atas, maka penelitian ini difokuskan untuk membahas hasil penelitian yang ditujukan untuk mengetahui penerapan kegiatan laboratorium kimia berbasis Mini-Project terhadap hasil belajar dan aktivitas siswa di salah satu SMA Negeri di Pandeglang. Kegiatan laboratorium yang dilaksanakan yaitu praktikum identifikasi formalin pada makanan menggunakan buah stroberi.

\section{METODE PENELITIAN}

Pada penelitian ini dilaksanakan pembelajaran kimia berbasis Mini-Project yang terdiri dari delapan tahap. Tahapan-tahapan pembelajaran kimia berbasis Mini-Project yaitu:

1. Pendahuluan, tahap ini meliputi pre-test, kemudian guru memberikan penjelasan tentang laboratorium Mini-Project yang akan dilaksanakan dan jadwal penelitian.

2. Pelatihan, tahap ini meliputi pembentukan kelompok berdasarkan hasil pre-test. Kemudian membahas soal-soal pretest yang tingkat kesalahannya paling tinggi.

3. Orientasi Masalah, tahap ini meliputi siswa diberi masalah, dan setiap kelompok bekerja pada satu sampel produk makanan yang akan diuji.

4. Merancang, tahap ini meliputi siswa melakukan tinjauan pustaka dari berbagai sumber, dan membuat proposal proyek. Sedangkan guru bertindak sebagai fasilitator, dan menyediakan waktu untuk menerima pertanyaan dari siswa.

5. Menyajikan Proposal, tahap ini meliputi siswa mengomunikasikan proposal ke kelompok lain melalui presentasi.

6. Pelaksanaan, tahap ini meliputi siswa melaksanakan proyeknya, dan guru bertindak sebagai fasilitator selain memandu penyelidikan.

7. Pelaporan dan Presentasi Hasil, tahap ini meliputi siswa membuat laporan proyek dari penyelidikan mereka. Kemudian siswa mengkomunikasikan laporan proyek mereka ke kelompok lain melalui presentasi.

8. Evaluasi, tahap ini meliputi siswa menyimpulkan konsep dari informasi yang telah diperoleh selama kegiatan laboratorium. Kemudian diadakan post-test.

Penelitian ini menggunakan metode quasyexperimental design. Melalui metode penelitian ini peneliti bermaksud mengumpulkan data dan mengamati aspek-aspek yang berkaitan erat dengan masalah yang diteliti. Desain yang digunakan dalam penelitian ini yaitu control group pre-test post-test design. Desain penelitian yang digunakan dalam penelitian dapat dilihat pada Tabel 1. 
Tabel 1. Desain Penelitian Control Group Pre-test and Post-test

\begin{tabular}{cccc}
\hline Kelompok & Pre-test & Perlakuan & Post-test \\
\hline Eksperimen & $\mathrm{O}_{1}$ & $\mathrm{X}$ & $\mathrm{O}_{2}$ \\
Kontrol & $\mathrm{O}_{1}$ & - & $\mathrm{O}_{2}$ \\
\hline
\end{tabular}

(Zahriah, Hasan, \& Jalil, 2016)

Teknik pengambilan sampel dalam penelitian ini menggunakan teknik purposive sampling. Teknik purposive sampling digunakan karena tidak semua sampel memiliki kriteria yang sesuai dengan fenomena yang ingin diteliti oleh peneliti. Melalui teknik purposive sampling peneliti dapat mempertimbangkan kriteria-kriteria yang harus dipenuhi oleh sampel-sampel yang akan digunakan dalam penelitian. Teknik pengumpulan data dilakukan secara tes dan non tes. Instrumen yang digunakan yaitu soal pretestposttest, dan lembar observasi aktivitas siswa.

Analisis instrumen soal pre-test dan posttest menggunakan teknik CVR (Content Validity Ratio) oleh delapan validator dengan nilai minimum CVR sebesar 0,78. Rumus untuk menghitung $C V R$ sebagai berikut:

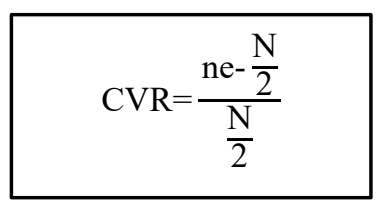

(Lupo \& Delbari, 2017)

Keterangan:

$C V R$ : Rasio validitas isi

$\mathrm{n}_{\mathrm{e}} \quad$ : Jumlah panelis setuju

$\mathrm{N}$ : Jumlah panelis

Tabel 2. Nilai Minimum CVR

\begin{tabular}{cc}
\hline Number of Panelists & Minimum Value \\
\hline 5 & 0,99 \\
6 & 0,99 \\
7 & 0,99 \\
8 & 0,78 \\
9 & 0,75 \\
10 & 0,62 \\
11 & 0.59 \\
dst. & dst. \\
\hline
\end{tabular}

(Lupo \& Delbari, 2017)
Data dalam penelitian ini yaitu data hasil belajar dan aktivitas siswa. Untuk menghitung data hasil belajar dan aktivitas siswa menggunakan rumus sebagai berikut:

\section{Menentukan Nilai Pre-test dan Post-test}

$$
X=\frac{\sum x}{\text { skor total }} x 100
$$

(Dewi, Sugiarta, \& Suarsana, 2015)

Keterangan:

$\mathrm{X} \quad$ : Nilai siswa

$\sum x \quad$ : Jumlah skor yang diperoleh siswa

\section{Menentukan Aktivitas Siswa}

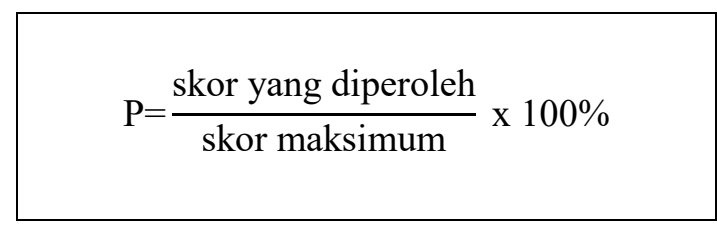

Keterangan:

P : Persentase aktivitas siswa

Skor max : Skor ideal

Tabel 3. Pedoman Kriteria Aktivitas

\begin{tabular}{cc}
\hline Persentase & Kriteria Aktivitas Siswa \\
\hline$\geq 81 \%$ & Sangat Tinggi \\
$61 \%-80 \%$ & Tinggi \\
$41 \%-60 \%$ & Sedang \\
$21 \%-40 \%$ & Rendah \\
$0 \%-20 \%$ & Sangat Rendah \\
\hline
\end{tabular}

(Yunita et al., 2016)

\section{HASIL DAN PEMBAHASAN HASIL}

Pada penelitian ini kegiatan laboratorium kimia yang dilakukan yaitu praktikum identifikasi formalin menggunakan buah stroberi. Ketika sampel teridentifikasi mengandung formalin maka akan terjadi perubahan warna dari jingga menjadi merah muda (Nuhman \& Wilujeng, 2017). Persamaan reaksi antara formaldehid dengan senyawa pelargonidin yang ada pada stroberi sebagai berikut: 


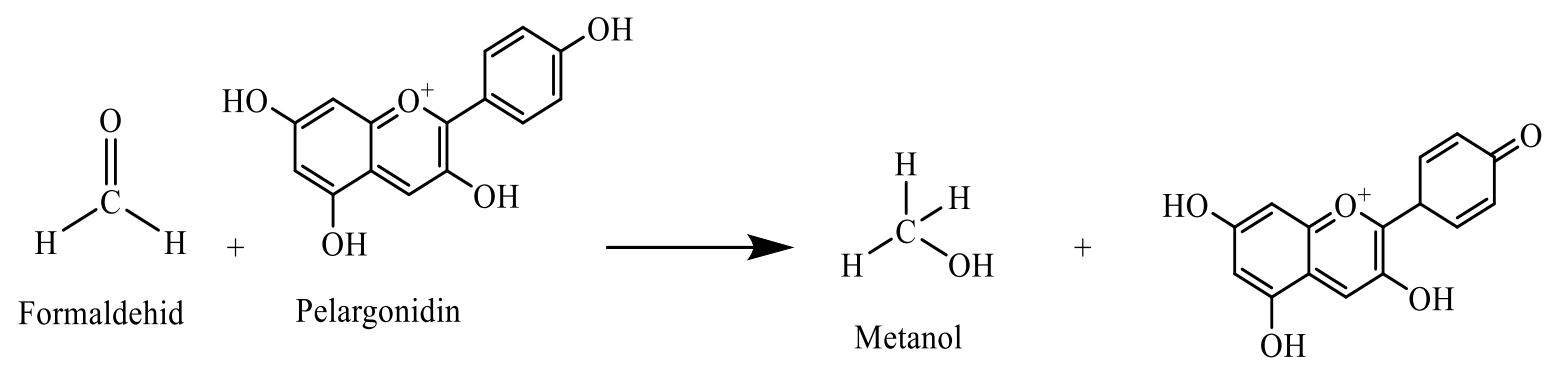

3,5,7-trihydroxy-2-(4-oxocyclohexa-2,5-dien-1yl)chromenylium

Gambar 1. Reaksi formaldehida dengan senyawa pelargonidin yang ada pada stroberi

Data yang diperoleh dalam penelitian ini yaitu data hasil belajar dan data aktivitas siswa. Data hasil belajar diperoleh dari hasil pre-test dan post-test, sedangkan data aktivitas siswa diperoleh melalui observasi. Data hasil belajar dapat dilihat pada Tabel 4.

Tabel 4. Data Hasil Belajar

\begin{tabular}{ccccc}
\hline \multirow{2}{*}{ Data } & \multicolumn{2}{c}{ Kelas } & \multicolumn{2}{c}{ Kelas Kontrol } \\
\cline { 2 - 5 } & $\begin{array}{c}\text { Eksperimen } \\
\text { Pre- } \\
\text { test }\end{array}$ & Post-test & $\begin{array}{c}\text { Pre- } \\
\text { test }\end{array}$ & Post-test \\
\hline Rata-rata & 54,53 & 84,53 & 54,84 & 60,00 \\
N & \multicolumn{2}{c}{32} & \multicolumn{2}{c}{32} \\
Gain & 30 & \multicolumn{2}{c}{5,16} \\
n-Gain & 0,6 & 0,1 \\
\hline
\end{tabular}

Tabel 4 menunjukkan nilai rata-rata hasil belajar. Pada kelas eksperimen rata-rata nilai pretest sebesar 54,53 dan rata-rata nilai post-test sebesar 84,53 . Sedangkan pada kelas kontrol ratarata nilai pre-test sebesar 54,84 dan rata-rata nilai post-test sebesar 60,00. Nilai gain pada kelas eksperimen sebesar 30, dan pada kelas kontrol sebesar 5,16. Nilai gain diinterpretasikan ke dalam nilai $n$-Gain.

Nilai $n$-Gain sebesar 0,6 menunjukkan bahwa penerapan kegiatan laboratorium kimia berbasis Mini-Project pada kelas eksperimen dapat meningkatkan hasil belajar dan aktivitas siswa dengan kategori "sedang". Nilai $n$-Gain sebesar 0,1 menunjukkan bahwa penerapan kegiatan laboratorium kimia berbasis $5 M$ pada kelas kontrol dapat meningkatkan hasil belajar dan aktivitas siswa dengan kategori "rendah".
Tabel 5. Rata-rata Aktivitas Siswa

\begin{tabular}{llcc}
\hline \multirow{2}{*}{ No } & \multicolumn{1}{c}{ Indikator } & \multicolumn{2}{c}{ Rata-rata Aktivitas Siswa (\%) } \\
\cline { 3 - 4 } Kelas & $\begin{array}{c}\text { Kelas } \\
\text { Kontrol }\end{array}$ \\
1. & Kesiapan Belajar & $95 \%$ & $77 \%$ \\
2. & $\begin{array}{l}\text { Keaktifan } \\
\text { Berdiskusi }\end{array}$ & $98 \%$ & $73 \%$ \\
3. & $\begin{array}{l}\text { Keaktifan } \\
\text { Praktikum }\end{array}$ & $97 \%$ & $74 \%$ \\
4. $\begin{array}{l}\text { Keaktifan } \\
\text { Mengerjakan }\end{array}$ & $97 \%$ & $68 \%$ \\
$\begin{array}{l}\text { LKPD } \\
\text { 5eaktifan }\end{array}$ & $92 \%$ & $52 \%$ \\
$\begin{array}{l}\text { Presentasi } \\
\text { Persentase rata-rata } \\
\text { aktivitas siswa }\end{array}$ & $95,8 \%$ & $68,8 \%$ \\
\hline
\end{tabular}

Tabel 5 menunjukkan pada kelas eksperimen persentase rata-rata aktivitas siswa sebesar 95,8\% dengan kategori "sangat tinggi", sedangkan pada kelas kontrol persentase rata-rata aktivitas siswa sebesar 68,8\% dengan kategori "tinggi". Hal ini menunjukkan bahwa aktivitas siswa ketika dilakukan penerapan kegiatan laboratorium kimia berbasis Mini-Project.

\section{Uji Validitas dan Reabilitas Instrumen}

Instrumen soal pre-test dan post-test divalidasi oleh delapan validator dengan nilai minimum CVR (Content Validity Ratio). Hasil yang didapatkan yaitu dari 30 butir soal yang telah diujikan terdapat 9 butir soal yang tidak memenuhi nilai minimum CVR (Content Validity Ratio) sehingga soal harus dihilangkan. Setelah itu dilakukan uji empirik menggunakan teknik $C F A$ (Confirmatory factor Analysis). Uji empirik dijicobakan kepada mahasiswa Untirta semester dua sebanyak 36 siswa. Instrumen soal yang dilakukan uji CFA ternyata tidak berhasil. Hal ini dikarenakan jumlah indikator pada soal yang diujicobakan terlalu sedikit. 
Uji reabilitas dilakukan pada masingmasing indikator soal. Indikator pertama didapatkan hasil reabilitas sebesar 0,611 dengan kategori reabilitasnya "tinggi". Sedangkan pada indikator kedua didapatkan hasil reabilitas sebesar 0,609 dengan kategori reabilitasnya "sedang". Sehingga dapat dikatakan bahwa instrumen yang dibuat pada penelitian ini reliabel.

Uji Normalitas

Tabel 6. Uji Normalitas

\begin{tabular}{lcccc}
\hline \multicolumn{5}{c}{ Kolmogorov-Smirnov } \\
\hline \multicolumn{1}{c}{ Data } & Statistik & df & Sig. \\
Kelas & Pretes & 0,134 & 32 & 0,151 \\
$\begin{array}{l}\text { Eksperime } \\
\text { n }\end{array}$ & $\begin{array}{c}t \\
\text { Postte } \\
\text { st } \\
\text { Kelas }\end{array}$ & 0,148 & 32 & 0,071 \\
Kontrol & $\begin{array}{c}t \\
\text { Prest }\end{array}$ & 0,130 & 32 & 0,180 \\
& $\begin{array}{c}\text { Poste } \\
\text { st }\end{array}$ & 0,130 & 32 & 0,185 \\
\hline
\end{tabular}

Pada pre-test eksperimen didapatkan Sig. sebesar 0,151. Pada post-test eksperimen didapatkan Sig. sebesar 0,071. Pada pre-test kontrol didapatkan Sig. sebesar 0,180. Pada posttest kontrol didapatkan Sig. sebesar 0,185. Sehingga dapat disimpulkan bahwa data berdistribusi normal. Data yang berdistribusi normal menunjukkan bahwa data yang digunakan dapat mewakili sampel yang digunakan dalam penelitian.

\section{Uji Homogenitas}

Tabel 7. Uji Homogenitas

\begin{tabular}{|c|c|c|c|c|}
\hline \multicolumn{5}{|c|}{ Uji Levene } \\
\hline Data & $\begin{array}{c}\text { Statisti } \\
k\end{array}$ & df1 & df2 & Sig. \\
\hline $\begin{array}{l}\text { Pretest Kelas Eksperimen } \\
\text { dan Kontrol }\end{array}$ & 0,092 & 1 & 62 & 0,762 \\
\hline $\begin{array}{l}\text { Posttest Kelas } \\
\text { Eksperimen dan Kontrol }\end{array}$ & 0,380 & 1 & 62 & 0,581 \\
\hline
\end{tabular}

Uji homogenitas dilakukan untuk mengetahui kesamaan antar dua keadaan atau proporsi (Wati, 2016). Pada Tabel 7 didapatkan Sig. sebesar 0,762 pada data pre-test, dan 0,581 pada data post-test. Sehingga dapat disimpulkan bahwa varian data pre-test dan data post-test adalah homogen. Data yang homogen menunjukkan bahwa sampel yang digunakan berasal dari populasi yang memiliki variansi yang sama.

\section{Paired Sample T Test}

Tabel 8. Uji Paired Sample T Test

\begin{tabular}{lcc}
\hline \multicolumn{1}{c}{ Data } & T & Sig. (2-tailed) \\
\hline Pair 1 Pretest-Posttest & $-15,640$ & 0,000 \\
$\begin{array}{l}\text { Eksperimen } \\
\text { Pair 2 Pretest-Posttest } \\
\text { Kontrol }\end{array}$ & $-33,000$ & 0,000 \\
\hline
\end{tabular}

Uji paired sample t test didapatkan hasil Sig. sebesar 0,000 atau $($ sig $)<(0,05)$. Sehingga dapat disimpulkan bahwa terdapat perbedaan ratarata hasil belajar antara pre-test dan post-test pada kelas eksperimen maupun kelas kontrol.

Independent Sample T Test

Tabel 9. Uji Independent Sample T Test

\begin{tabular}{ccc}
\hline Data & $\mathbf{T}$ & Sig. (2-tailed) \\
\hline Hasil Belajar Siswa & 11,968 & 0,000 \\
\hline
\end{tabular}

Uji independent sample t test digunakan untuk mengetahui perbedaan rata-rata dua sampel yang tidak berpasangan. Uji independent sample $t$ test pada penelitian ini didapatkan hasil Sig. sebesar 0,000 atau $($ sig $)<(0,05)$. Sehingga dapat disimpulkan bahwa terdapat perbedaan rata-rata hasil belajar antara kelas kontrol dan kelas eksperimen setelah penerapan kegiatan laboratorium kimia berbasis Mini-Project.

\section{Uji Anova Dua Jalur}

Tabel 10. Uji Anova Dua Jalur

\begin{tabular}{ccc}
\hline Data & df & Sig. \\
\hline Metode & 1 & 0,000 \\
Aktivitas & 2 & 0,000 \\
Metode*Aktivitas & 1 & 0,046 \\
\hline
\end{tabular}

Uji anova dua jalur digunakan untuk mengetahui perbedaan rata-rata lebih dari dua sampel yang tidak berpasangan. Uji anova dua jalur pada penelitian ini didapatkan hasil Sig. sebesar 0,000 atau $(s i g)<(0,05)$. Sehingga dapat disimpulkan bahwa terdapat perbedaan rata-rata hasil belajar dan aktivitas siswa antara kelas kontrol dan kelas eksperimen setelah penerapan kegiatan laboratorium kimia berbasis Mini-Project.

Perbedaan uji independent sample $t$ test dan uji anova dua jalur pada penelitian ini terletak pada banyaknya sampel yang dibandingkan. Uji independent sample $t$ test membandingkan ratarata dua sampel yang tidak berpasangan, yaitu hasil 
belajar kelas kontrol dan hasil belajar kelas eksperimen. Sedangkan uji anova dua jalur membandingkan rata-rata lebih dari dua sampel yang tidak berpasangan, yaitu hasil belajar dan aktivitas siswa pada kelas kontrol maupun hasil belajar dan aktivitas siswa pada kelas eksperimen.

\section{Effect size}

Hasil perhitungan effect size yaitu sebesar 0,99 dan termasuk dalam kategori "besar". Hal ini menunjukkan bahwa penerapan kegiatan laboratorium kimia berbasis Mini-Project berpengaruh besar terhadap hasil belajar dan aktivitas siswa.

\section{PEMBAHASAN}

Penerapan Kegiatan Laboratorium Kimia

\section{Berbasis Mini-Project Terhadap Hasil Belajar}

Uji hipotesis paired sample $t$ test digunakan untuk mengetahui ada tidaknya perbedaan rata-rata hasil belajar antara pre-test dan post-test pada kelas eksperimen maupun kelas kontrol. Berdasarkan uji paired sample $t$ test didapatkan nilai signifikansi sebesar 0,000 atau < 0,05 yang berarti terdapat perbedaan rata-rata hasil belajar pre-test dan post-test pada kelas eksperimen, maupun perbedaan rata-rata hasil belajar antara pre-test dan post-test pada kelas kontrol. Hasil uji paired sample t test dapat dilihat pada Gambar 2.

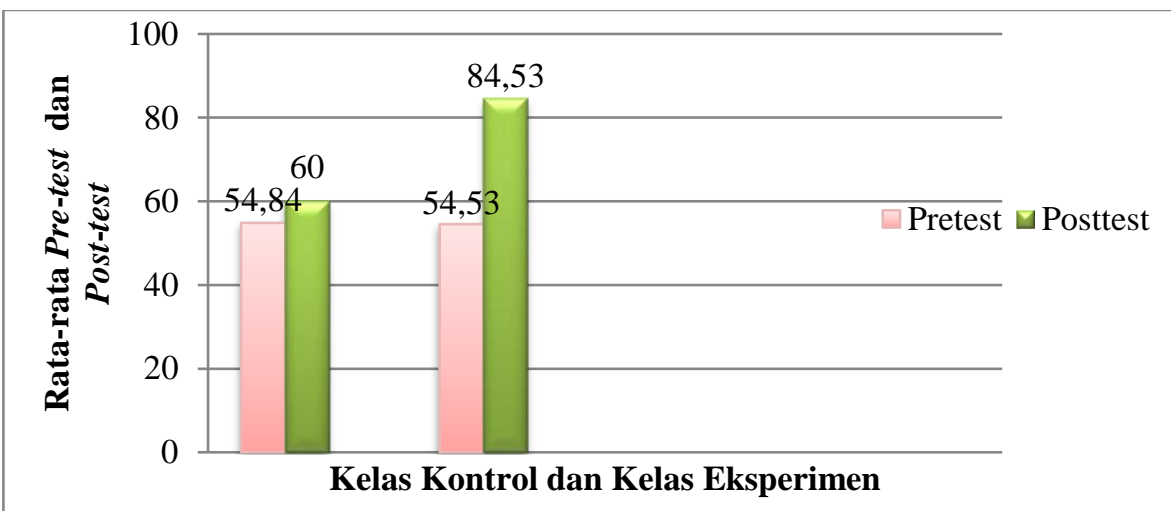

Gambar 2. Rata-rata Pretest-Posttest Kelas Kontrol dan Kelas Eksperimen

Uji independent sample $t$ test digunakan untuk mengetahui ada tidaknya perbedaan rata-rata hasil belajar kelas eksperimen dan kelas kontrol. Berdasarkan uji independent sample $t$ test didapatkan nilai signifikansi sebesar 0,000 atau <
0,05 yang berarti terdapat perbedaan rata-rata hasil belajar kelas eksperimen dan kelas kontrol. Hasil uji independent sample $t$ test dapat dilihat pada Gambar 3.

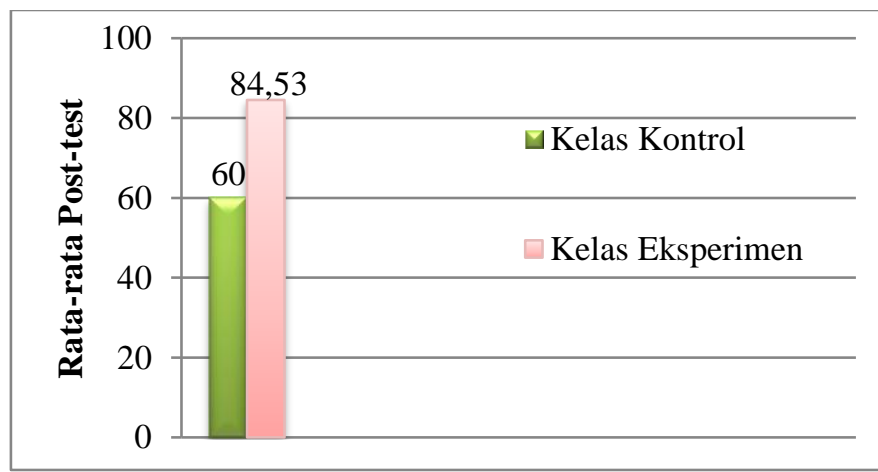

Gambar 3. Rata-rata Post-test Kelas Kontrol dan Kelas Eksperimen 
Berdasarkan hasil uji paired sample t test dan uji independent sample $t$ test yang telah dilakukan didapatkan signifikansi sebesar 0,000 atau $>0,05$. Hal tersebut membuktikan bahwa hasil belajar lebih meningkat pada penerapan kegiatan laboratorium kimia berbasis Mini-Project, jika dibandingkan dengan penerapan kegiatan laboratorium kimia berbasis $5 M$. Selain itu, Hakim juga telah membuktikan bahwa pembelajaran berbasis Mini-Project dapat meningkatkan pemahaman siswa (Hakim et al., 2015).

\section{Penerapan Kegiatan Laboratorium Kimia Berbasis Mini Project Terhadap Aktivitas Siswa}

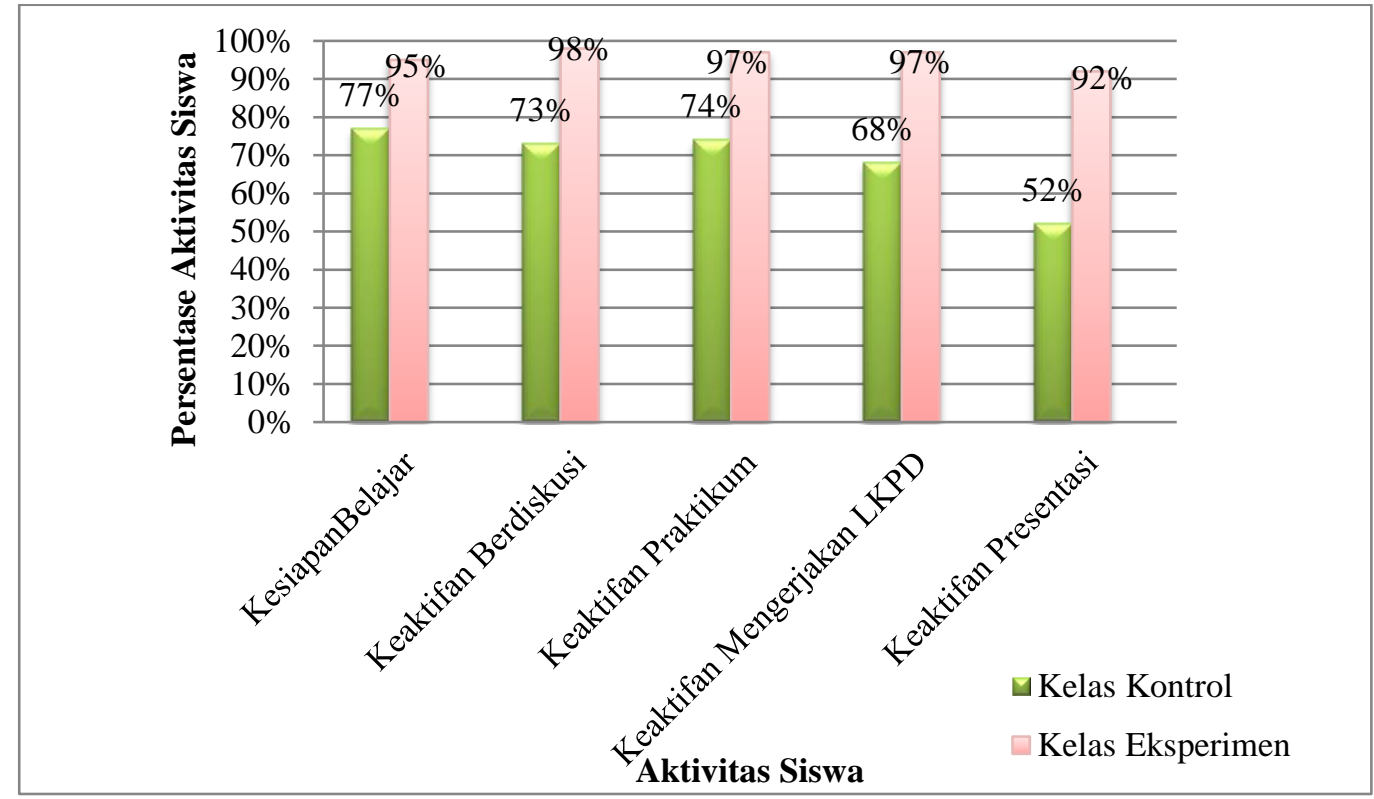

Gambar 4. Persentase Aktivitas Siswa

Setelah diketahui persentase aktivitas rata-rata persentase aktivitas siswa pada kelas siswa dari setiap indikatornya, kemudian dihitung kontrol dan kelas eksperimen.

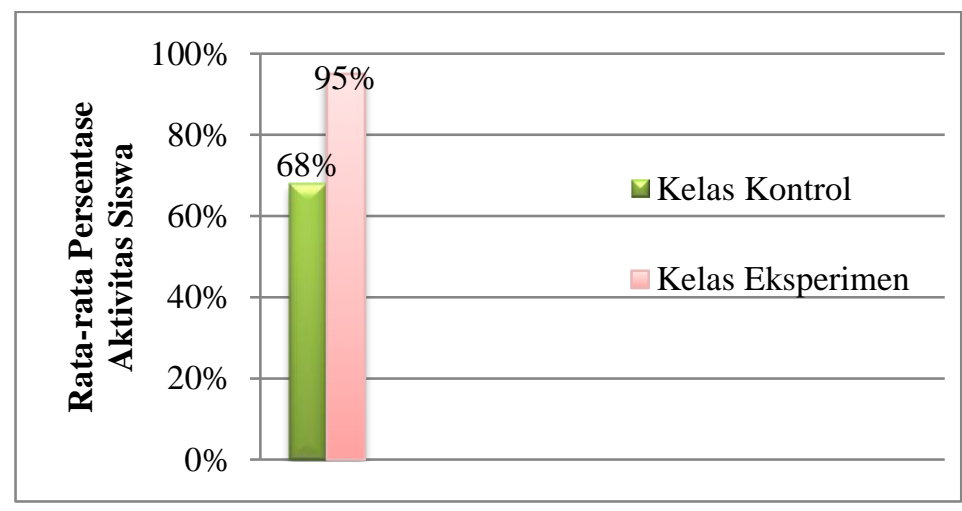

Gambar 5. Rata-rata Aktivitas Siswa

Berdasarkan Gambar 5 diketahui bahwa rata-rata persentase aktivitas siswa di kelas eskperimen lebih tinggi dari pada rata-rata persentase aktivitas siswa di kelas kontrol. Ratarata persentase aktivitas siswa di kelas eksperimen sebesar 95\% dengan kategori "sangat tinggi". Sedangkan rata-rata persentase aktivitas siswa di kelas kontrol sebesar 68\% dengan kategori "tinggi". Hal ini menunjukkan bahwa penerapan 
kegiatan laboratorium kimia berbasis Mini-Project dapat meningkatkan aktivitas siswa.

Ketika siswa terlibat lebih aktif dalam kegiatan merancang sebuah praktikum, pengalaman praktikum yang diperoleh akan mendorong siswa untuk memperdalam pemahaman mereka tentang konsep yang sudah mereka pelajari. Penelitian sebelumnya juga telah membuktikan bahwa pembelajaran berbasis MiniProject dapat meningkatkan keterampilan kerja praktek dan motivasi siswa (Rosa et al., 2018). Selain itu terdapat juga penelitian yang menyatakan bahwa kegiatan praktikum berbasis Mini Project dapat memberikan pengalaman eksperimen siswa (Silverstein, 2016).

\section{Penerapan Kegiatan Laboratorium Kimia Berbasis Mini Project Terhadap Hasil Belajar dan Aktivitas Siswa}

Selanjutnya dilakukan analisis lebih lanjut untuk mengetahui apakah terdapat perbedaan ratarata hasil belajar dan aktivitas siswa pada kelas kontrol dan kelas eksperimen. Berdasarkan uji anova dua jalur yang telah dilakukan didapatkan signifikansi sebesar 0,000 atau $<0,05$ maka $\mathrm{H}_{0}$ ditolak; $\mathrm{H}_{1}$ diterima. Hal ini membuktikan bahwa terdapat perbedaan rata-rata hasil belajar dan aktivitas siswa pada kelas kontrol dan kelas eksperimen.

\section{KESIMPULAN}

Penelitian yang telah dilakukan menunjukkan bahwa penerapan kegiatan laboratorium kimia berbasis Mini-Project dapat meningkatkan hasil belajar dan aktivitas siswa. Hasil belajar dan aktivitas siswa meningkat dikarenakan melalui kegiatan laboratorium kimia berbasis Mini-Project memungkinkan siswa belajar proses. Belajar proses memungkinkan tercapainya tujuan belajar dari segi kognitif, afektif, dan psikomotor. Pengalaman yang diperoleh siswa ketika merancang praktikumnya sendiri, akan mendorong siswa untuk lebih memahami materi yang mereka pelajari.

Beberapa saran yang dapat dikemukakan dari hasil penelitian ini adalah 1) Bagi peneliti yang ingin menerapkan kegiatan laboratorium kimia berbasis Mini-Project untuk lebih memperhatikan sistematika lembar kerja peserta didik (LKPD), agar peserta didik lebih terangsang lagi dalam meningkatkan hasil belajar dan aktivitas belajarnya; 2) Penelitian ini hanya difokuskan untuk melihat bagaimana penerapan kegiatan laboratorium kimia berbasis Mini-Project terhadap hasil belajar dan aktivitas siswa. Bagi peneliti lain yang ingin melakukan penelitian yang sama disarankan untuk meneliti variabel lain dari peserta didik.

\section{DAFTAR PUSTAKA}

Aeni, A. Q., Saptorini, \& Supardi, K. I. (2017). Keefektifan Pembelajaran Praktikum Berbasis Guided-Inquiry terhadap Keterampilan Laboratorium Siswa. Chemistry in Education, 6(1), 8-13.

Agustin, M., B, N. A. Y., \& Rusdi. (2017). Upaya Meningkatkan Aktivitas Belajar Siswa dengan Menerapkan Model Pembelajaran Problem Posing Tipe Pre Solution Posing di SMP Negeri 15 Kota Bengkulu. Jurnal Penelitian Pembelajaran Matematika Sekolah (JP2MS), 1(1), 66-72.

Barus, E. L., \& Sani, R. A. (2017). Pengaruh Model Pembelajaran Latihan Inkuiri Terhadap Hasil Belajar Siswa pada Materi Pokok Usaha dan Energi di Kelas X Semester II. Jurnal Inovasi Pembelajaran Fisika (INPAFI), 5(4), 16-22.

Dewi, M. A. C., Sugiarta, I. M., \& Suarsana, I. M. (2015). Penerapan Pembelajaran Kooperatif Teknik Kancing Gemerincing untuk Meningkatkan Keaktifan dan Prestasi Belajar Matematika Siswa SD. Jurusan Pendidikan Matematika, Fakultas Matematika Dan Ilmu Pengetahuan Alam Universitas Pendidikan Ganesha Singaraja, Indonesia, 3(1).

Erlinda, N. (2017). Peningkatan Aktivitas dan Hasil Belajar Siswa melalui Model Kooperatif Tipe Team Game Tournament pada Mata Pelajaran Fisika Kelas X di SMK Dharma Bakti Lubuk Alung. Tadris: Jurnal Keguruan Dan Ilmu Tarbiyah, 02(1), 49-55. https://doi.org/10.24042/tadris.v2i1.1738

Hakim, A., Liliasari, Kadarohman, A., \& Syah, Y. M. (2015). Making a Natural Product Chemistry Course Meaningful with a Mini Project Laboratory. Journal of Chemical Education. https://doi.org/10.1021/ed500930s

Kurniawati, L., Akbar, R. O., \& Misri, M. A. 
(2015). Pengaruh Penerapan Metode Pembelajaran Praktikum terhadap Keterampilan Berpikir Kritis Matematika Siswa Kelas VIII SMPN 3 Sumber Kabupaten Cirebon. Tadris Matematika, 4(2), 62-74.

Lupo, T., \& Delbari, S. A. (2017). A knowledgebased exploratory framework to study quality of Italian mobile telecommunication services. Springer. $\quad$ https://doi.org/10.1007/s11235017-0380-6

Nuhman, \& Wilujeng, A. E. (2017). Pemanfaatan Ekstrak Antosianin dari Bahan Alam untuk Identifikasi Formalin pada Tahu Putih. Jurnal Sains, 7(14), 8-15.

Pamungkas, M. S. H., Mulyani, S., \& Saputro, S. (2017). Penerapan Model Pembelajaran POE dengan Metode Praktikum untuk Meningkatkan Rasa Ingin Tahu dan Prestasi Belajar Kimia Siswa. PAEDAGOGIA Jurnal Penelitian Pendidikan, 20(1), 46-60. https://doi.org/10.20961/paedagogia.v20i1.16 596

Permatasari, O. I., \& Marwoto, P. (2017). Penerapan Model Pembelajaran PredictObserve-Explain Berbasis Kontekstual untuk Meningkatkan Aktivitas dan Pemahaman Konsep Siswa SMP. Jurnal Ilmu Pendidikan Fisika, 2(2), 50-53.

Rosa, C. H., Antelo, F., \& Rosa, G. R. (2018). Kinetics of Thermal-Degradation of Betanins: A Teaching Mini-Project for Undergraduates Employing the Red Beet. Journal of Food Science Education, 17, 104110. https://doi.org/10.1111/15414329.12147

Silverstein, T. P. (2016). The Alcohol Dehydrogenase Kinetics Laboratory:
Enhanced Data Analysis and StudentDesigned Mini-Projects. Journal of Chemical Education.https://doi.org/10.1021/acs.jcheme d. $5 \mathrm{~b} 00610$

Suarta, I. K., Adi, I. P. P., \& Satyawan, I. M. (2017). Pengaruh Penerapan Model Pembelajaran Kooperatif Tipe Student Teams Achievement Division (STAD) Terhadap Hasil Belajar Teknik Dasar Passing Sepak Bola. E-Journal PJKR Universitas Pendidikan Ganesha, 8(2).

Taher, T. (2019). Peningkatan Aktivitas Belajar Siswa Melalui Pembelajaran Kimia Berbasis Budaya Lokal. Jambura Journal of Educational Chemistry, 1(2), 69-73.

Wati, W., \& Fatimah, R. (2016). Effect Size Model Pembelajaran Kooperatif Tipe Numbered Heads Together (NHT) terhadap Kemampuan Berpikir Kritis Siswa pada Pembelajaran Fisika. Jurnal Ilmiah Pendidikan Fisika 'AlBiRuNi',,' 05(2), 213-222. https://doi.org/10.24042/jpifalbiruni.v5i2.121

Yunita, N. N., Wahyuni, S., \& Suharso, P. (2016). Penerapan Metode Resitasi Untuk Meningkatkan Aktivitas dan Hasil Belajar Siswa Pada Mata Pelajaran Ekonomi Materi Pendapatan Nasional (Studi Kasus Pada Mata Pelajaran Ekonomi Kompetensi Dasar Pendapatan Nasional Kelas XI IPS 2 di MAN 2 Jember The Implemen. JURNAL EDUKASI, 3(3), 47-51.

Zahriah, Hasan, M., \& Jalil, Z. (2016). Penerapan Pemecahan Masalah Model Polya untuk Meningkatkan Kemampuan Analisis dan Hasil Belajar pada Materi Vektor di SMAN 1 Darul Imarah. Jurnal Pendidikan Sains Indonesia, 04(02), 151-161. 